\title{
Employee health and wellness in South Africa: The role of LEGISLATION AND MANAGEMENT STANDARDS
}

\author{
Authors: \\ Charlotte Sieberhagen \\ Sebastiaan Rothmann ${ }^{1}$ \\ Jacobus Pienaar ${ }^{1}$
}

\section{Affiliations:}

${ }^{1}$ WorkWell, Research Unit for People, Policy and

Performance, North-West

University, South Africa

\section{Correspondence to:}

Sebastiaan Rothmann

e-mail:

ian@ianrothmann.com

\section{Postal address:}

P O Box 8060

Swakopmund, Namibia, 9000

\section{Keywords:}

standards; workers; wellbeing; legislation; stress

\section{Dates:}

Received: 12 Jul. 2008

Accepted: 18 Mar. 2009

Published: 29 May 2009

How to cite this article: Sieberhagen, C., Rothmann, S., \& Pienaar, J. (2009).

Employee health and wellness in South Africa: The role of legislation and management standards. $S A$ Journal of Human Resource Management/SA Tydskrif vir Menslikehulpbronbestuur, 7(1), Art. \#144, 9 pages. DOI: 10.4102/sajhrm.v7i1.144

This article is available at: http://www.sajhrm.co.za

(c) 2009. The Authors. Licensee: OpenJournals Publishing. This work is licensed under the Creative Commons Attribution License.

\begin{abstract}
The aim of this study was to investigate the role that legislation and management standards might play in ensuring occupational health and wellness in South Africa. The Occupational Health and Safety Act of 1993 determines that an employer must establish and maintain a work environment that is safe and without risk to the health of employees. It seems that there is a lack of guidance in the laws and statutes with regard to dealing with employee health and wellness. A management standards approach, which involves all the role players in the regulation of employee health and wellness, should be implemented.
\end{abstract}

\section{INTRODUCTION}

According to world-wide estimates, job-related accidents and illnesses claim more than two million lives annually, while 270 million accidents and 160 million illnesses occur over the same period worldwide. These accidents and illnesses account for $4 \%$ of the cost of the global economy of the Gross Domestic Product (GDP) annually. World estimates show that small- and medium-size enterprises account for $90 \%$ of those enterprises where poor working conditions are prevalent (South African Department of Labour, 2004). Estimations, which are generally regarded as underestimations, show that 1.1 million deaths occur worldwide because of illnesses or injuries at work. This adds up to 3000 deaths caused by work-related factors every day (Takala, 1998).

Politicians, policymakers, labour unions and employers need to be convinced of the importance of occupational health and safety (Rantanen, Lehtinen \& Savolainen, 2004). This is particularly important in developing countries that also face occupational health and safety hazards but lack the resources to deal with these hazards. According to Rantanen et al. (2004), approximately 2.4 billion of the 3.2 billion workers in the world (i.e. 80\%) live in developing countries, compared to the 600 million in industrialised countries. However, developing countries produce only $20 \%$ of the GDP in the world (compared to $80 \%$ of the industrialised countries).

Occupational accidents and diseases amount to a cost for South Africa in the region of 3.5\% of the GDP, which translates to about R30 billion per annum (South African Department of Labour, 2004). A total of 122889 employees fall victim to accidents or sickness as a direct result of their work, and almost $1 \%(0.72 \%$, or 884 employees) of these are fatal. The number of man-days lost annually due to sickness is put at over 12 million, with further losses due to labour unrest (Workmen's Compensation Fund, 1999). The South African government gives occupational health and safety high priority, and advocacy and awareness campaigns as well as inspection blitzes are being carried out regularly (Mdladlana, 2007). The South African Department of Labour listed mining, construction, steel and agriculture as high-risk sectors of employment. Employees in these sectors are at a higher risk of getting hurt or being involved in accidents at work. Between 1997 and 2006, an average of 173 mine workers died annually in South African gold mines (De Beer, 2007). The Occupational Health and Safety Act (South Africa, 1993b) deals quite well with issues regarding health and safety in the workplace. In terms of the Act, safety is defined as 'to keep employees free from hazard' and health is defined as 'free from illness or injury attributable to occupational causes'. The problem with this definition is that it is not clear whether it also refers to psychological illness (e.g. because of occupational stress).

Legislation might be necessary to ensure that the safety, health and wellness of employees are taken seriously. However, it seems that priorities in industrialised and developing countries differ substantially. According to Rantanen et al. (2004), priorities regarding employee health and safety in industrialised countries include stress, the aging workforce, the right to know, informed consent and transparency, work with or exposure to chemicals, ergonomics, allergies, the quality of indoor air, new technologies, management and safety culture, and occupational health services. Priorities regarding employee health and safety in developing countries include agriculture, dangerous occupations, the transfer of hazardous technologies, major accidents and fires, safety, housekeeping and productivity, occupational and work-related diseases, toxic metals and solvents, organic dusts, vulnerable groups, child labour, heat stress and heavy physical work. Although some overlap exists (e.g. in terms of exposure to toxic metals and exposure to chemicals), it is clear that employee safety, health and wellness are given higher priority in industrialised countries as compared to developing countries. Health and safety aspects are covered by occupational health and safety legislation, but legislation regarding employee wellness still lacks to a large extent. Psychosocial stressors seem to be a priority in industrialised countries, while issues such as dangerous occupations and heavy physical work are important focus areas in developing countries.

Wynne and Rafferty (1999) point out that psychosocial stressors at work were traditionally regarded as unimportant and even a taboo subject in Europe and the United States of America. This resulted in a lack of consideration of the effect of psychological stressors on employees. Furthermore, the trend in organisations was to treat psychosocial stressors as an individual problem to be managed by enhancing the coping skills of the individual employee. In other words, a worker-orientated approach prevails, for instance by improving the skills of employees to manage, resist or reduce stress, as opposed to 
a job- or organisational-oriented approach, for instance by job redesign or in some way transforming the incapacitating corporate culture or management style (Taris, Kompier, Geurts, Schreurs \& Schaufeli, 2003).

There have been a number of developments in recent years that have begun to lead a change in approach to dealing with wellness in the workplace (Wynne \& Rafferty, 1999). In the first place, occupational stress has begun to lose its taboo status and its previous association with mental illness in the public mind. Popular media, conferences, newspaper articles and television programmes deal with wellbeing or employee wellness in an open manner. Secondly, medical practitioners have begun to use the terms 'stress' and/or 'burnout' as a reason for absence from work. Thirdly, the growing exposure of society to the issue has led to the issue being talked about in the workplace.

\section{Definition of terms}

The World Health Organization (WHO) defines health as 'a complete state of physical, mental and social well-being and not just the absence of disease' (World Health Organization, 2002, p. 2). Since 1950, the International Labour Organization (ILO) and the $\mathrm{WHO}$ have shared a common definition of occupational health. The definition reads:

Occupational health should aim at: the promotion and maintenance of the highest degree of physical, mental and social well-being of workers in all occupations; the prevention amongst workers of departures from health caused by their working conditions; the protection of workers, in their employment situation, from risks resulting from factors adverse to health; the placing and maintenance of the worker in an occupational environment adapted to his physiological and psychological needs and capabilities; and, to summarize, the adaptation of work to man and of each man to his job.

(Stellman, 1998, p. 28)

Although this definition of health includes physical and psychological dimensions, legislation is interpreted to focus on physical health (e.g. the prevention and management of occupational diseases) rather than psychological health (e.g. the prevention and management of stress and depression).

Nonetheless, the ILO and the WHO are committed to primary prevention means and are of the opinion that intensive actions for better work environments are required in virtually every country (Goldstein, Helmer \& Fingerhut, 2001). Criteria and actions need to be considered for the planning and design of healthy and safe work environments that are conducive to physical, psychological and social wellbeing (Goldstein et al., 2001). Wellness can be defined as the experience of optimal health, good relationships with others, being emotionally and cognitively well stimulated and experiencing significance and purpose in life (Els, 2005). A person who is in a state of wellness can therefore maximise his or her potential. Rothmann and Rothmann (2006) define employee health and wellness as a state in which employees are energetic, motivated, healthy, productive and committed to the organisation and its goals.

In studying employee health and wellness, various paradigms can be used. Strümpfer (1995) refers to three paradigms that could be relevant for studying employee health and wellness They are the pathogenic paradigm (which focuses on the origins of illness), the salutogenic paradigm (which focuses on the origins of health) and the fortigenic paradigm (which focuses on the origins of strength). The salutogenic and fortigenic paradigms are part of the positive psychology movement (Seligman, 2002). Seligman and Csikszentmihalyi (2000, p. 5) suggest that the purpose of positive psychology is 'to begin to catalyse a change in the focus of psychology from preoccupation only with repairing the worst things in life to also building positive qualities'. Applied to the work context, Luthans (2002) recommends that positive organisational behaviour be researched and practiced. In positive organisational behaviour positive-oriented human resource strengths and psychological capacities are the focus of study and intervention. Nelson and Simmons (2003) suggest that work stress should be viewed from a more holistic perspective incorporating 'eustress'. Eustress is associated with the positive effects of the stress response.

In line with the assumptions of the pathogenic paradigm, the traditional focus of research and practice regarding employee health and wellness was illness, distress, dissatisfaction and unhappiness (Nelson \& Simmons, 2003). However, research and practice in employee health and wellness should also focus on the origins of health and strength (Strümpfer, 1995). Therefore, the focus of employee health and wellness should not only be on the factors in the workplace that affect employees negatively (e.g. stress and strain), but also on how to promote the positive aspects of employee health and wellness (e.g. good supervisory relationships, collegial support, growth opportunities and adequate job resources).

\section{Importance of health and wellness in organisations}

Studies in the United Kingdom (UK) showed that stress and stress-related illness were second only to musculoskeletal disorders as the major cause of occupational ill-health (Jones \& Hodgson, 1998). Stress resulted in 6.5 million working days lost to industry and commerce in the UK, accompanied by a financial burden to the economy of $£ 3.7$ billion per annum. In a 1997 survey in the Netherlands, 58\% of Dutch employees indicated their pace of work to be 'high' more than $50 \%$ of the time, compared to a European average of $42 \%$. Work disability rates in the Netherlands are twice as high as in other European countries. One-third of the disability benefit recipients are assessed to be disabled for work on mental health grounds (Lourijsen, Houtman, Kompier \& Gründemann, 1999).

In 1998, mental health disorders in the Netherlands were the largest diagnostic group for work incapacitation (32\%), followed by musculoskeletal disorders. Inspection revealed that $80 \%$ of the mental health cases did not suffer from major psychopathology (e.g. psychosis, neurosis or personality disorder), but from adjustment disorders (including job stress and burnout). Specific problem areas include physical workload, mental workload, general working conditions, unfavourable social climate and low payment. $12 \%$ of the workers' days of absence were because of mental or psychological disorders, with a sickness absence rate of $5.6 \%$ amounting to $\$ 25$ billion in 1995 , which is about $8 \%$ of the Dutch GDP. However, productivity was also higher in the Netherlands than in other European countries.

Poor health is an outcome of stress, which can be used to ascertain whether workplace pressures have positive and motivating (salutogenic) or negative and damaging (pathogenic) effects. However, poor health may not necessarily be indicative of workplace stress. Individuals may, for example, be unwell because they choose not to live a healthy lifestyle or may be unaware of how to do so (Cartwright \& Cooper, 2002). The experience of high levels of stress may lead to feelings of anger, anxiety, depression, nervousness, irritability, tension and boredom. The negative effects of stress on the individual may lead to poorer job performance and motivation, lower creativity, a reduced quality of social relations and overall diminished individual effectiveness (Schabracq, Winnubst \& Cooper, 2003). Effects directly related to job stress that may influence the organisation include low production and increased production errors, increased accidents, high labour turnover, increased absenteeism and increased medical costs.

Low production, high production errors and accidents, high labour turnover, increased absenteeism and high medical costs can all be considered symptomatic of the experience of workplace stress. Statistics confirm that at any given time onefourth of South Africa's workforce is affected by problems that 
contribute to a deterioration in performance at work, and that South Africa's workforce productivity is ranked 31st out of 45 counties (Noemdoe, 2002). In 1996, the cost of injuries at work in South Africa amounted to R4.7 billion a year (Noemdoe, 2002). Also, South African employees are generally unhealthy, due to unhealthy living conditions in squatter camps and unhealthy lifestyles and diets due to their economic circumstances (Mead, 1998). Furthermore, almost one-quarter of the economically active population is HIV positive, which contributes to high labour turnover rates and lower worker productivity and constitutes an increased burden on employee benefit programmes (The South African Institute of International Affairs, 2004). In South Africa, it is estimated that 6.3 days per employee per annum are lost to unapproved absences from work (Vaida, 2005). About 4.5\% of the South African workforce are absent on any given day, although the absenteeism rate is sometimes as high as $18 \%$ in some South African organisations (Vaida, 2005).

South Africa's population is estimated at 47.9 million people. Africans make up $80 \%$ of the population at nearly 38.1 million. KwaZulu-Natal has the largest share of the population (approximately 21\%), followed by Gauteng (20\%). 51\% (approximately 24.3 million) of the population are female (Statistics South Africa, 2007). The economically active population for all race groups is estimated at 16 million. Most people employed by the formal sector work within community, social and personal services, wholesale or manufacturing (Perold \& Jooste, 2006).

Stress is regarded as a serious occupational risk in South Africa (Barkhuizen \& Rothmann, 2004; Pienaar \& Rothmann, 2005; Rothmann, 2005; Temkin, 2004). The ten most general claims accepted by medical schemes are for the treatment of stressrelated illnesses (i.e. high blood pressure, high cholesterol, asthma, depression, menopause, type 1 diabetes, epilepsy, type 2 diabetes, ischaemic heart diseases and gastro-oesophageal reflux). Furthermore, $75 \%$ of the visits to primary health care facilities are stress-related (Van der Merwe, 2005). However, a strong pathogenic approach still exists in that it is managed as a cause of illness and the positive effects of job stress are not explored.

Rothmann (2005) analysed occupational stressors in 14 different occupations in South Africa and concluded that stress levels are high in workers in some occupations, especially in the health sector (such as hospital pharmacists, nurses and emergency workers), correctional officers, university educators, call centre operators and police officers. Inadequate salaries, colleagues not doing their work, poorly motivated co-workers and insufficient staff were severe stressors identified across many occupations. Statistics show that an average of 10000 police officers in South Africa are absent from work daily because of high levels of occupational stress (Pienaar \& Rothmann, 2005). Educators (specifically in secondary schools) in South Africa also seem to experience high levels of stress. 20\% of the educators in Gauteng are absent for more than 10 days per year (Naidu, 2005). Executives in South Africa also experience high stress levels. Their stress levels are fuelled by the exchange rate volatility, commodity prices, fluctuating interest rates, changing legislation and empowerment charters (Temkin, 2004).

Occupational stress could be a serious threat to employees, organisations and to South Africa as a country. Research has indicated the negative effect of stress on the health and wellness of employees, and therefore this can also influence organisations negatively. Organisations can feel the impact of stress in increased absenteeism, higher staff turnover and lower productivity of employees, which will ultimately influence the organisation's bottom-line. These effects can also have an adverse impact on the economic growth of South Africa through lower productivity and increased numbers of employees who are incapable or unwilling to work.

\section{Regulating employee health and wellness}

There are different role players that can participate in efforts to ensure the health and wellness of employees. The four major role players can include the employee, by means of the things he or she does to keep him- or herself well (Cartwright \& Cooper, 2002); labour/trade unions (Cousins et al., 2004) through negotiating health and wellness issues of their employees on their behalf with their employers; management of organisations by means of the implementation of employee health and wellness or assistance programmes; and the national government, by means of the laws and national strategy it imposes.

Legislation could play an important role in governing employee health and wellness, but that would only involve national government as a role player and might be bureaucratic. An alternative might be to involve all the role players in the development of management standards to ensure the health and wellness of employees. However, the government can have a large influence by imposing legislation that promotes and protects employee health and wellness and by providing the infrastructure to support a management standards approach.

According to Kompier and Schaufeli (2001), an active government policy towards job stress may prevent it from remaining a mere taboo subject, and may put it on political and company agendas. Modern working conditions legislation should not only address traditional health and safety issues, but also psychosocial work characteristics (e.g. job content and social relations at work). From the point of view of the modern worker such legislation is crucial. Legislation and corresponding national working conditions administrative infrastructure (occupational health and safety services) are important to stimulate organisations to take action. Special attention should be given to small- and medium-sized companies that often lack special expertise for risk assessment and prevention (Kompier \& Schaufeli, 2001).

The aim of this study was to investigate the role that legislation and management standards might play to ensure occupational health and wellness, and to make recommendations regarding a national strategy in order to promote employee health and wellness in South African organisations.

\section{RESEARCH DESIGN}

\section{Research approach}

A review of the business, organisational psychology and health sciences literature about health and wellness legislation (applicable to work) was performed.

\section{Research method}

The electronic databases for Psychology (PsycINFO), EBSCOHOST, ScienceDirect, Emerald, ISI Web of Knowledge and SAEPublications were systematically searched prior to more detailed searches. Keywords used in the literature searches included occupational health, wellness, occupational stress, legislation and standards. Reference lists of articles and books were reviewed for additional publications that may not have been indexed properly and not found via electronic searches. Internet searches of health and safety organisations (e.g. www. hse.gov.uk, www.tno.nl) and government websites (www. labour.gov.za) were also performed.

The sample consisted of documents, acts, book chapters and peer-reviewed articles published from 1994 to 2008. The selection criteria for this review include those sources and studies that a) were written in English or Afrikaans, and b) examined legislation and health and wellness regulation in Europe and in developing countries (including South Africa). Nearly 200 sources were reviewed, of which 34 are referenced in this article. 


\section{RESULTS}

Next, trends in legislation in the literature were analysed, followed by a review of relevant South African legislation and a description of the management standards approach.

\section{International trends regarding health and wellness legislation}

In Europe, three developments in the early 1990s gave rise to an increased need for practical ways for managers to prevent stress and manage work wellness, namely an increasing incidence of occupational stress, requirements of European and national legislation and an increase of employee litigation (Geurts \& Gründemann, 1999). In 1989, the European Commission published its 'Framework directive on the introduction of measures to encourage improvements in the safety and health of workers at work' (Geurts \& Gründemann, 1999). These requirements had to be made into laws in each of the member states of the European Union. The directive required employers to avoid risks, to evaluate the risks that cannot be avoided to combat risks at their source, to keep themselves informed of the latest advances in technology and scientific findings concerning workplace design, and to consult workers and their representatives and allow them to take part in the discussions on all questions relating to safety and health at work. Employers were required to be in possession of an assessment of the risks to safety and health at work and decide on the protective measures to be taken (Kompier \& Cooper, 1999). Although various European countries implemented legislation to regulate employee health and wellness, the practices in the UK, the Netherlands, Denmark, Finland and Germany will be considered below.

United Kingdom. In the UK, provisions were catered for in the Health and Safety at Work Act (1974) and Management of Health and Safety at Work Regulations (1992). These laws made risk assessment and management essential. An important court ruling was in the case of John Walker, a social services manager (Walker versus Northumberland County Council). Walker lodged a case against his former employers for failure to prevent him from trying to cope with a health-endangering workload. Although there were reports on out-of-court settlements regarding stress claims in the UK, the Walker case was the first of its kind to come before a UK court (Whatmore, Cartwright \& Cooper, 1999). The court ruled in favour of the plaintiff and stated that there is no reason why psychological damage should be excluded from the scope of an employer's duty of care. The Court held that employers had a duty not to cause their employees psychiatric damage by giving too much work and/or insufficient backup support. The general principle is that an employer is usually entitled to assume that the employee can withstand the pressures of the job. However, if it is reasonably foreseeable that there is a risk of injury (which must be a clinically recognisable condition) due to stress at work, then the employer owes the employee a positive duty to make the working environment less stressful (Hawson, 2003)

The Netherlands. In the Netherlands, work stress has become an important policy issue and provisions were catered for in the Working Condition Act (WCA) of 1990 (Lourijsen et al., 1999). The WCA goes beyond merely protecting employee health and safety by promoting their wellbeing within the organisation. The WCA states that the workplace, working methods, tools, machines and the work content should be in accordance with the personal characteristics of employees, and that monotonous and repetitive work should be avoided. It is believed that an active policy of employers to foster safety, health, and wellbeing must be based on a thorough written and regularly conducted inventory and assessment of all work-related risks, including psychosocial risks. Risk inventory and assessment should include a plan of action to reduce risks and be sent to the Occupational Health and Safety Services (OHSSs) for approval. Employers should engage experts from the OSHHs to assist in carrying out risk assessments and develop a plan of action, and they need to give social-medical guidance to sick employees and carry out periodical medical examinations. The WCA is administered by the Labour Inspectorate, which can fine employers or prosecute them criminally. Compliance is encouraged by providing information and disseminating knowledge, by granting the development of instruments for assessing psychosocial risks and by stimulating preventative programs. OHSSs are independent commercial enterprises that operate in the private market by selling their services to companies. In 1998, 95\% of Dutch companies had a contract with an OHSS (Lourijsen et al., 1999).

Denmark. In Denmark the Working Environment Act of 1975 lays down the functions and responsibilities of the institutions, authorities and persons responsible for the working environment in all sectors except domestic work and the armed forces. The Act makes it compulsory for work to be conducted in such a way that employees' health and safety are protected. Its objective is to ensure that working conditions are such that workers will not be subjected to accident or disease and/or to physical and psychological problems (Netterstrǿm, 1999). In Denmark, psychosocial risk factors are divided into two categories, depending on their cause. The first category comprises psychosocial problems arising from management's general decisions concerning the enterprise, the interaction between management, the employees and their representatives, the interaction between employees themselves, or factors arising from external circumstances (e.g. pay, promotion, training, job uncertainty, harassment and bullying). The second category comprises psychosocial problems that are directly or indirectly related to work methods, products used or the physical framework for performance (e.g. organisation of the workplace, noise, repetitive work, risk of violence, solitary work and human service work) (Netterstrǿm, 1999).

Finland. The Finnish Occupational Health Care Act of 1978 specifies that all employers are obliged to organise occupational health services for their employees, that such services must be available for the self-employed, that prevention be emphasised and that sufficient staff should be available for the service system (Kalimo \& Toppinen, 1999). According to the Act and the lower level statutes, working conditions, including work organisation and psychosocial factors, have to be monitored systematically. The statutes stipulate that occupational health professionals must participate in regular training. The targets of occupational health care cover the prevention of risks, a healthy and safe working environment, a well-functioning work organisation, the prevention of work-related diseases and the maintenance and improvement of the individual's ability to work. Furthermore, the Occupational Safety Act of 1987 states that employers have to ensure that work is not harmful to the (physical and mental) health of employees. It stipulates that employers should take into account the mental wellbeing of the employee when planning the work and work conditions. Furthermore, the employee's psychological resources have to be taken into account in adjusting the work and work methods to suit the worker. Training and guidance in risk prevention must be given.

Germany. The German industrial relations system is characterised by cooperative conflict solution mechanisms based on societal and industrial consensus. Safety and health are affected by the national labour law and by social security law (Beermann, Kuhn \& Kompier, 1999). Those who can contribute to reducing the risks of accidents and hazards to health are obliged to cooperate, viz. employers, work councils as representatives of employees, work safety experts, company doctors and health and safety committees. The employer is responsible for implementing health and safety measures to protect employees through early prevention and the informing and instructing of employees. Work councils have a duty to monitor inadequacies in preventive measures, organise work, co-determine the health and safety measures to be carried out, provide assistance regarding safety and health and ensure the right to information 
and participation. Work and safety experts and company doctors advise the employer and other persons responsible for health and safety, check safety aspects before they are introduced and see that health and safety measures are carried out. However, Beermann et al. (1999) point out that most German employers still think of occupational stress as a personal issue rather than a work-related issue.

In European countries, stress prevention directives have clearly been added to the laws on working conditions (Kompier, De Gier, Smulders \& Draaisma, 1994). It seems that in European countries that have such a statutory framework, corporate initiatives are implemented to prevent stress. In South African labour law, statutory modifications of the common law were effected by imposing minimum conditions of employment for employees, promoting equal opportunities for races and genders, promoting collective bargaining and developing specialist tribunals to create equitable principles for the workplace (Grogan, 2005).

\section{South African labour legislation}

The main employment-related statutes in South Africa that influence employee's health and wellness by protecting them include the Constitution of the Republic of South Africa, the Occupational Health and Safety Act, the Labour Relations Act, the Basic Conditions of Employment Act, the Compensation for Occupational Diseases and Injuries Act, the Unemployment Insurance Act, the Employment Equity Act and the Skills Development Act.

The Constitution of the Republic of South Africa (South Africa, 1996) (Section 23) can have implications for the health and wellness of South African employees. The Constitution states that:

Everyone has the right to fair labour practices; every worker has the right to form and join a trade union, to participate in the activities and programs of a trade union, and to strike; every employer has the right to form an employer's organization and to participate in the activities thereof and every trade union, employer's organization and employer has the right to engage in collective bargaining. (Grogan, 2005, p. 129)

Therefore, every South African employee has the right to be protected from unfair labour practices.

The Occupational Health and Safety Act (no. 85 of 1993) (South Africa, 1993b) applies to all employers, with the exception of miners, owners of certain shipping vessels, those exempted by the Minister and temporary employment services. It establishes a council to advise the Minister on occupational health and safety. This Act imposes a general duty on employers to provide a reasonably safe and healthy working environment, to provide information, training and supervision as is necessary to ensure health and safety and to report to an inspector any incident in which an employee dies or is injured or when dangerous situations arise. Employees are obliged to obey health and safety rules and to report unsafe or unhealthy situations or incidents to employers or health and safety representatives. Employers with more than 20 employees must, after consultation with employees or their representatives, appoint one or more full-time employee as health and safety representative, and employers are obliged to provide training and facilities to these representatives. Employers with more than one safety representative must establish health and safety committees, with which they are obliged to consult on health and safety issues. Inspectors are empowered to enter the premises of employers and examine compliance with the Act (Grogan, 2005). Under this Act special mention is made regarding facilities regulation.

Facilities regulations make provision for the following in the workplace: sanitation facilities, facilities for safekeeping, changing rooms, signs for prohibition of smoking, eating and drinking in certain workplaces, dining rooms, drinking water, conditions of rooms and facilities and offences and penalties (Grogan, 2005). This ensures minimum standards regarding issues that might affect the health of employees at work, and thereby employee health and wellness.

The Labour Relations Act (no. 66 of 1995) (South Africa, 1995) aims to encourage collective bargaining and the settlement of disputes by enhancing powers of forums designed to facilitate these objectives. It contains specific rules and rights on contravention or infringement, which fall under the auspices of either the Commission for Conciliation, Mediation and Arbitration (CCMA), accredited bargaining councils or a specialised Labour Court. A commissioner, bargaining council or labour court refers disputes not settled by conciliation to arbitration. Furthermore, employers have to consult with workplace forums on a regular basis (Grogan, 2005). Therefore, the Act ensures that employees' voices can be heard and that employee health and wellness issues can be addressed though workplace forums that employers have to consult.

The Basic Conditions of Employment Act (no. 75 of 1997) (South Africa, 1997a) ensures that working hours do not exceed certain maxima, that employees are granted adequate breaks during the working day, that they are given prescribed annual and sick leave and that they are paid a premium for overtime and work on Sundays and public holidays. It requires employers to maintain records and to provide the means by which rates of pay and working hours are to be calculated. The Act also regulates the minimum notice that must be given on termination of the contract. Furthermore, it creates an Employment Conditions Commission that advises the Minister and labour inspectorate to mediate disputes arising under the Act (Grogan, 2005). This Act protects the health and wellness of employees through strict rules that ensure rest periods for employees, adequate leave and overtime pay.

Code of Good Practice: Working Time: The objective of this code is to provide information and guidelines to employers and employees concerning the arrangement of working time and the impact of working time on the health, safety and family responsibilities of employees. This Code governs the regulation of working time through Section 7 of the Basic Conditions of Employment Act and requires employers to regulate the working time of each employee - with due regard to the health and safety of employees. This Code is of particular significance for employees who perform shift work or regular night work. The regulation of working time is closely connected to the protection and promotion of the health and safety of employees. Employers must conduct a risk assessment regarding the effects of night and shift work on employees, implement appropriate measures to eliminate or control hazards identified in the risk assessment and train and supply information to employees about the risks to their health and safety and the measures taken to control such risks. Employers who engage employees to perform regular night work must ensure that the employees are informed of the health and safety hazards associated with the work that they will be expected to perform (Department of Labour, 2008).

The Compensation for Occupational Diseases and Injuries Act (no. 130 of 1993) (South Africa, 1993a) ensures that employees or their dependants who have suffered injury, illness or death arising from the execution of their work are compensated. This Act excludes soldiers, police officers, domestic workers and contract workers. It specifies that compensation is payable only if the accident that caused the injury, illness or death occurred within the scope of the employee's employment and was not predictable. No payments in respect of temporary disabilities of three days or less, those resulting from wilful misconduct by employees or non-physical damages like pain and suffering (Grogan, 2005) are catered for. This Act influences health and wellness of employees in that it ensures compensation for employees whose health was negatively affected while performing their work. 
The Unemployment Insurance Act (no. 30 of 1966) (South Africa, 1966) provides for payment of benefits to employees who have lost their employment through pregnancy or other circumstances beyond their control. The Act only applies if the claimant has been in employment previously and is seeking and willing to accept work, or is unable to find work because of a scheduled illness (Grogan, 2005). This Act can influence the health and wellness of women in that it ensures income while they are on maternity leave. The Basic Conditions of Employment Act only stipulates that women should receive four months' maternity leave, but the maternity leave does need not be paid leave. In view of the current economic situation the Unemployment Insurance Act reduces stress for women, who otherwise would have had to cope without an income for the stipulated four-month period.

The Skills Development Act (Act 56 of 1997) (South Africa, 1997b) establishes a National Skills Authority, Sector Education and Training Authorities (SETAs) and Skills Development Planning Units (Grogan, 2005). This Act influences the health and wellness of employees in that it promotes the development of skills levels of employees. Increased skills levels can reduce stress because employees who previously lacked skills will feel more confident and experience less job stress than when they had to perform jobs for which they did not have the necessary competencies.

Employees' duties: Workers must take reasonable precautions to ensure their own health, wellness and safety at work. They must follow any precautions and rules concerning safety and health (Department of Labour, 2008). They must report any unsafe circumstances or an accident to the safety representative as soon as possible. Anyone who acts in a reckless way or damages any safety equipment can be charged. Also, if the worker does this damage on purpose, then the employer can claim damages from him or her (Grogan, 2005). This indicates that although organisations should take responsibility for the health and wellness of their employees, the individuals must take some responsibility themselves to ensure their own and their colleagues' health and wellness.

Currently employee health and wellness is not explicitly covered by legislation in South Africa. Many organisations still lack policies regarding employee health and wellness.

\section{The role of management standards in managing employee health and wellness}

Cousins et al. (2004) argue that it is critical that stress related to work must be risk assessed and managed like any other hazard. Legislation is not the only way through which health and wellness issues of employees in South Africa can be addressed - another possibility can be the introduction of management standards for employee health and wellness. Where government enforces legislation, the use of management standards is more self-regulatory.

The term 'management standard' refers to a set of principles agreed on by organisations in consensus in order to enhance health and wellness by identifying work-related stress hazards and reducing associated risks. Although a management standard does not necessarily impose obligations of adherence, it is important that a management standard regarding work-related stress and the influence on employee health and wellness in South Africa be developed.

By using the management standards approach, all the role players can be involved in the governance of employee health and wellness. The role players can agree on the standards to be used by organisations to measure themselves against the management standard and 'states to be achieved' (Cousins et al., 2004, p. 121). The different role players in employee health and wellness should all be involved in the development of policy to govern or regulate employee health and wellness on organisational level. A fine example of the development and use of management standards to manage work-related stress can be found in the UK in the form of the UK Health and Safety Executive (HSE) management standards (Mackay, Cousins, Kelly, Lee \& McCaig, 2004). These standards are designed to help simplify risk assessment for stress, to encourage employers, employees and their representatives to work in partnership to address work-related stress throughout the organisation and to provide a yardstick by which organisations can gauge their performance in tackling the key causes of stress.

The UK Health and Safety Executive (HSE) (2001) have identified six stressors that may negatively influence employee wellness, viz. job demands, control over work, support, relationships at work, role in the organisation and change in the organisation (Cousins et al., 2004). Management standards include targets for organisations to aim towards or 'states to be achieved' (Cousins et al., 2004, p. 121). One standard is identified for each risk factor. Job demands, for example, covers workload, work patterns and the work environment. The standard includes guidance on what should be happening in the organisation if the standard is being achieved. The target for demands is then achieved if $85 \%$ of employees can cope with the demands of their jobs (Cousins et al. 2004). As for the other stressors, control over work refers to how much say employees have in the way they do their work; support refers to encouragement, sponsorship and resources provided by the organisation, line management and colleagues; relationships at work refers to promoting positive working attitudes to avoid conflict and dealing with unacceptable behaviour; role in the organisation refers to whether employees understand their role in the organisation and whether the organisation ensures that employees do not have conflicting roles; and change refers to how organisational change is managed an communicated in the organisation. Management standards have the following implications for employers (Cousins et al., 2004). Employers will have to:

- assess the risk for and potential causes of stress within the organisation, e.g. by looking at sickness absence patterns and conducting surveys;

- use the information to assess the organisation's performance in relation to the six factors; and

- decide on improvement targets and action steps in conjunction with staff or their representatives.

\section{DISCUSSION}

The aim of this study was to investigate the role that legislation and management standards might play to ensure occupational health and wellness in South African organisations. It seems that the South African labour law is not clear on the definition of occupational health and still favours physical health. Employee wellness is also not defined within South African labour law. The law is clear in defining health and safety and in paying attention to health and safety. While inadequate safety measures usually have an immediate effect, inadequate attention to psychological health may take considerable time before it manifests as an occupational disease.

The South African labour relations framework provides a mechanism for employee health interventions. However, there is a lack of guidance in the case law and statutes with regard to dealing with psychological stress. Employers have to identify work activities that will expose employees to physical and psychological risks, but currently little is done in terms of risk analysis and occupational stress interventions. South Africa needs a national strategy to deal with physical and psychological risks at work that influence the health and wellness of employees.

The Occupational Health and Safety Act requires an employer to provide and maintain a healthy working environment by providing safe systems of work, plants and machinery; taking reasonable steps to eliminate or mitigate potential hazards; making arrangements for ensuring safety when working with or 
transporting articles or substances; and establishing the health and safety hazards attached to work performed. The Act further requires employers to implement and provide precautionary measures in order to protect employees; provide the necessary information, training and supervision; and to not permit employees to do any work unless the precautionary measures have been taken. Although the Act provides for precautions to prevent the negative effects on employee's health, the Act does not explicitly prescribe any prohibiting of factors that might influence the wellness of employees.

To comply with the Occupational Health and Safety Act, employers will need to identify the health and safety hazards (including chemical, physical, radiation, biological, ergonomical and psychosocial hazards) in their specific workplace, measure these and control exposure to them. Work activities might expose employees to physical (e.g. working on a scaffold or working in confined spaces) and psychological (being subjected to numerous deadlines and office politics) risks. Employers must ensure that workers are informed and understand the health and safety hazards of work or risks associated with these hazards.

Implicit within the South African labour relations practice is the understanding that every manager is expected to demonstrate skills in performance management through coaching and support. However, it seems that there is a lack of guidance in the case law and statutes with regard to dealing with psychological stress - analysis of cases show that while there are cases of illhealth and injury because of work, only physical symptoms of ill-health are normally attended to.

It is important that South African labour legislation be modernised in order to address not only traditional health and safety issues but also psychosocial work characteristics (roles, demands and relationships at work). It is important that risk assessment regarding psychosocial issues at work be conducted and that special attention be given to small- and medium-sized companies that often lack special expertise for risk assessment and risk prevention. It is important for national government to set up the necessary legislation and administrative infrastructure in order to stimulate organisations to take action regarding psychosocial issues that are affecting their employees' health and wellness.

There is proof of the symptomatic experience of workplace stress by South African employees, and this is affecting their health and wellness. Organisations experience the symptoms through unapproved absences from work (Vaida, 2005), low productivity (Noemdoe, 2002) and high labour turnover rates (The South African Institute of International Affairs, 2004). There is ample guidance in the literature on how to manage the outcomes of stress and proof of its effect on the health and wellness of employees. The best practices and examples regarding stress legislation can be taken from a number of European countries such as the UK, Ireland, Belgium, the Netherlands and Sweden. The UK's HSE provides clear guidelines on how to address stress and psychosocial issues at work.

To manage health and wellness risks, it is essential for employers to conduct a risk assessment. This requires that they identify hazards and assess the risks that they pose to the health and safety of employees. The results of this risk assessment must be recorded. Employers must implement appropriate measures to eliminate or control hazards identified in the risk assessment. Furthermore, they must provide training and supply information to employees about the risks to their health and safety and the measures taken to control such risks. Elected worker health and safety representatives and committees are entitled to participate in the risk assessment and control of hazards.

The employee health and wellness practitioner plays an important coordinating role in the occupational health, safety and wellness system, and also monitors the level of legal compliance in organisations. It is important that guidelines should be provided to employee health and wellness practitioners regarding employee health and wellness management and compliance in order to optimise employee health and wellness in their organisations.

Employees are obliged to obey health and safety rules and to report unsafe or unhealthy situations or incidents to employers or health and safety representatives. They must take care of their own health, wellness and safety and those of others who might be affected by their behaviour. Furthermore, they should cooperate with the employer where the Act imposes such a duty, give information to an inspector from the Department of Labour if required, wear the prescribed clothing and use the prescribed safety equipment and report unsafe or unhealthy conditions to the employer or the health and safety representative.

Currently the Labour Relations Act (no. 66 of 1995) (South Africa, 1995) aims to encourage collective bargaining and the settlement of disputes by enhancing powers of forums designed to facilitate these objectives. Therefore, the Act ensures that employees' voices can be addressed through workplace forums that employers have to consult. This Act can play a major role in the management standards approach to employee health and wellness in that it will encourage role players to negotiate issues regarding employee health and wellness.

\section{Recommendations}

South Africa can learn from the European approach to health and safety that encourages primary prevention by giving priority to collective protective measures over individual protective measures (Mackay et al., 2004). The situation in South Africa is unique, but note can be taken of best practices in other countries. However, the challenge lies in finding our own solution to problems that affect the health and wellness of South African employees. A national strategy needs to be developed that addresses the factors that influence employee health, wellness and safety in South African organisations. Although organisations can play a major role in addressing work-related issues, government should play a role in other factors such as primary health care and living conditions of citizens.

Labour legislation in South Africa provides a framework for addressing employee health and wellness. It is recommended that legislation should only play a role in the interim to govern employee health and wellness. Legislation is bureaucratic in nature in that it is governed one-sidedly by only one role player in employee health and wellness: the national government. Alternatively, control measures (management standards) can be used for practical workplace action. The management standards approach is more self-governed, and involves all the role players (employees, labour unions, organisations and government) in the regulation of employee health and wellness. Role players in the South African labour context should work together to compile a national strategy to address the issues that influence employee health and wellness in the South African context today.

In order to promote employee health and wellness strategies, certain conditions are prerequisites:

- $\quad$ Legal and policy instruments. Legislation and regulations should be regarded as adequate, and laws and regulations that exist should be adequately enforced. South African organisations lack adequate policies to govern employee health and wellness. It is important for organisations to develop employee health and wellness policies in order to regulate employee health and wellness in their organisations. Management standards should promote the use of primary interventions such as job redesign in favour of tertiary interventions that focus on individuals (Mackay et al, 2004).

South Africa should also establish an executive body to deal with policy and operational matters relating to occupational health, wellness and safety matters. Within 
such a body, infrastructure can be established through a special commission to take the lead in the overall reduction of work-related stress in South Africa. Currently such a body, the HSE, already exists within the UK, and South Africa can learn from their already established practices. The proposed South African health, wellness and safety body should give guidance to South African organisations on how to deal with health, wellness and safety issues of their employees. Special attention should be given to how organisations should conduct risk assessment of health, wellness and safety issues and how they should manage the improvement of health, wellness and safety in their organisations.

- Infrastructure. A working labour inspection system and an occupational health service system are key elements in supporting adequate occupational health and safety legislation, regulations and standards, e.g. through the setting of minimum standards and through adherence to regulations. The education of health care professionals is a crucial aspect in this regard.

- Information. Knowledge and facts are needed if occupational health, wellness and safety are to be improved in South Africa. Researchers should undertake longitudinal research regarding employee health, wellness and safety. Research regarding employee health and wellness should consider multiphase and multiple case study designs. This will enable researchers to better understand issues regarding employee health, wellness and safety. Organisations and employee health, wellness and safety practitioners will benefit from such research in that they will have proof of the effects of stress or interventions on employees over time. Multiple case studies on the impact of stress on employee health and wellness may lead to evidence-based prevention in South Africa. Kompier, Cooper and Geurts (2000) found in their multiple case study that it was to the benefit of both the individual and the organisation when preventative measures were based on adequate diagnoses of risk factors and risk groups and when the measures were implemented in a proper way. In order to develop the management standards and to conduct risk assessment in South Africa, a relevant measurement tool should be developed. The indicator tool is a way in which performance can be measured against a standard. In setting a threshold for work-related stress, the management standard could indicate whether organisations are conforming to good practices, which may prevent the occurrence of occupational stress (Mackay et al., 2004). Government can support the process in funding the development of such a tool and providing it to organisations free of charge. South African 'cut-off points regarding work-related stress should be developed in order for South African organisations to determine whether or not they are negatively influencing their employees' health and wellness.

- Education and training. Educational institutions in South Africa should be involved in occupational health and safety training. This should be supplemented by conferences, symposia, and workshops. Employees should be trained on how to address and promote their own health and wellness, labour unions should be trained on issues of employee health and wellness of their members and also how to negotiate the issues with employers, and relevant people in organisations should be trained on how to effectively manage and implement employee health and wellness in their organisations.

- Recording, storing and disseminating information. Registers for the collection of employee health and wellness information are crucial in obtaining a systematic evaluation of the occupational health and wellness situation in a specific organisation, community and country. Examples of registers include cancer registers, registers for occupational diseases and work accidents, registers on numbers and causes of deaths and registers on communicable diseases. Journals, newsletters and websites could deal with the dissemination of information to other professions and health care professionals.

\section{REFERENCES}

Barkhuizen, N., \& Rothmann, S. (2004). Burnout of academic staff in a higher education institution. In 2nd South African Work Wellness Conference, 25-26 March 2004 (n.p.). Potchefstroom, North West Province, South Africa: Potchefstroom University.

Beermann, B., Kuhn, K., \& Kompier, M. (1999). Germany: Reduction of stress by health circles. In M. Kompier \& C.L. Cooper (Eds.), Preventing stress, improving productivity: European case studies in the workplace (pp. 222-240). London: Routledge.

Cartwright, S., \& Cooper, C.L. (2002). ASSET: An organizational stress screening: The management guide. Manchester: RCL Ltd.

Cousins, R., Mackay, C.J., Clarke, S.D., Kelly, C., Kelly, P.J., \& McCaig, R.H. (2004). 'Management standards' and workrelated stress in the UK: Practical development. Work $\mathcal{E}$ Stress, 19, 113-136.

De Beer, L. (2007, September). Risiko's verhoog soos myne verdiep [Risks increase as mines deepen]. Beeld. Retrieved May 16, 2008, from http://www.news24.com/Beeld/ Vermaak/Boeke/0,3-2109-2112_2296026,00.html

Department of Labour. (2004). Safety and health at work commemoration. News release. Retrieved May 5, 2008, from http://www.labour.gov.za/media/statement.jsp

Department of Labour. (2008). Basic Conditions of Employment Act: Code of Good Practice on The Arrangement of Working Time. Retrieved May 15, 2008, from http://www.labour.gov. za/download/6050/Code

Els, D. (2005). Wellness: A pig's life. First behaviour-based wellness book. Pretoria: MC Printers.

Geurts, S., \& Gründemann, R. (1999). Workplace stress and stress prevention in Europe. In M. Kompier \& C.L. Cooper (Eds.), Preventing stress, improving productivity: European case studies in the workplace (pp. 1-8). London: Routledge.

Goldstein, G., Helmer, R., \& Fingerhut, M. (2001). Mobilizing to protect worker's health: The WHO global strategy on occupational health and safety. African Newsletter, 11(3), 58.

Grogan, J. (2005). Workplace law. (8th edn.). Cape Town: Juta.

Hawson, K. (2003). Stress images - Walker vs Northumberland County Council. Legal commentary. Retrieved May 20, 2008, from http://www.legalday.co.uk/lexnex/keeble03/ keeble090503b.htm

Health and Safety Executive (HSE). (2001). Tackling work-related stress: A managers' guide to improving and maintaining employee health and well-being. HS(G)218. Sudbury: HSE Books.

Jones, J.R., \& Hodgson, J.T. (1998). Self-reported work-related illness in 1995: Results from a household survey. London: HSE Books.

Kalimo, R., \& Toppinen, S. (1999). Finland: Organisational wellbeing. Ten years of research and development in a forest industry corporation. In M. Kompier \& C.L. Cooper (Eds.), Preventing stress, improving productivity: European case studies in the workplace (pp. 52-83). London: Routledge.

Kompier, M., \& Cooper, C.L. (1999). Introduction: Improving work, health and productivity through stress prevention. In M. Kompier \& C.L. Cooper (Eds.), Preventing stress, improving productivity: European case studies in the workplace (pp. 1-9). London: Routledge.

Kompier, M., Cooper, C.L., \& Geurts, S.A.E. (2000). A multiple case study approach to work stress prevention in Europe. European Journal of Work and Organizational Psychology, 3, 371400.

Kompier, M., De Gier, E., Smulders, P., \& Draaisma, D. (1994). Regulations, policies and practices concerning work stress in five European countries. Work E Stress, 8, 296-318.

Kompier, M., \& Schaufeli, W.B. (2001). Managing job stress in the Netherlands. International Journal of Stress Management, 8(1), 15-34. 
Lourijsen, E., Houtman, I., Kompier, M., \& Grüdemann, R. (1999). The Netherlands: A hospital, 'Healthy working for health'. In M. Kompier \& C.L. Cooper (Eds.), Preventing stress, improving productivity: European case studies in the workplace (pp. 86-118). London: Routledge.

Luthans, F. (2002). The need for and meaning of positive organizational behaviour. Journal of Organizational Behavior, 23, 695-706.

Mackay, C.J., Cousins, R., Kelly, P.J., Lee, S., \& McCaig, R.H. (2004). Management standards and work-related stress in the UK: Policy background and science. Work E Stress, 18, 91-112.

Mdladlana, M. (2007). The Labour Minister's speech at the International Occupational Health and Safety Day in Rustenburg on 4 May 2007. Retrieved May 11, 2008, from http://www. labour.gov.za/media/speeches.jsp?speechdisplay_id=12150

Mead, P. (1998). Workplace wellness makes cents. People Dynamics, November/December, 24-26.

Naidu, B. (2005, 10 July). R6m to help teachers fight stress. Sunday Times Metro, p. 1.

Nelson, D.L., \& Simmons, B.L. (2003). Health psychology and work stress: A more positive approach. In J.C Quick \& L.E. Tetrick (Eds.), Handbook of occupational health psychology (pp. 193-203). Washington, DC: American Psychological Association.

Netterstrøm, B. (1999). Self-rule on Route 166. An intervention study among bus drivers. In M. Kompier \& C.L. Cooper (Eds.), Preventing stress, improving productivity: European case studies in the workplace (pp. 175-193). London: Routledge.

Noemdoe, G. (2002). Helping the healthy stay healthy. People Dynamics, 20(5), 31.

Perold, H., \& Jooste, P. (2006). Employment and unemployment in South Africa: A brief description. Johannesburg: Business Trust.

Pienaar, J., \& Rothmann, S. (2005). Suicide ideation in the South African Police Service. South African Journal of Psychology, 35(1), 58-72.

Rantanen, J., Lehtinen, S., \& Savolainen, K. (2004). The opportunities and obstacles to collaboration between the developing and developed countries in the field of occupational health. Toxicology, 198(1/3), 63-74.

Republic of South Africa. (1966). Unemployment Insurance Act, No. 30 of 1966. Pretoria: Government Printers.

Republic of South Africa. (1993a). Compensation for Occupational Diseases and Injuries Act, No. 130 of 1993. Pretoria: Government Printers.

Republic of South Africa. (1993b). Occupational Health and Safety Act, No. 85 of 1993. Pretoria: Government Printers.

Republic of South Africa. (1995). Labour Relations Act, No. 66 of 1995. Pretoria: Government Printers.

Republic of South Africa. (1996). Constitution of the Republic of South Africa, No. 108 of 1996. Pretoria: Government Printers.

Republic of South Africa. (1997a). Basic Conditions of Employment Act, No. 75 of 1997. Pretoria: Government Printers.

Republic of South Africa. (1997b). Skills Development Act, No. 56 of 1997. Pretoria: Government Printers.
Rothmann, S. (2005, August). Job stress prevention in South Africa. Paper presented at the Second ICOH International Conference on Psychosocial Factors at Work, Okayama, Japan.

Rothmann, S., \& Rothmann J.C. (2006). The South African Employee Health and Wellness Survey: User manual. Potchefstroom: Afriforte.

Schabracq, M.J., Winnubst, J.A.M., \& Cooper, C.L. (2003). The handbook of work and health psychology. Washington, DC: John Wiley \& Sons.

Seligman, M.E.P. (2002). Positive psychology, positive prevention and positive therapy. In C.R. Snyder \& S.J. Lopez. (Eds.), Handbook of positive psychology (pp. 410-421). New York: Oxford University Press.

Seligman, M.E.P., \& Csikszentmihalyi, M. (2000). Positive psychology: An introduction. American Psychologist, 55, 5-14.

Statistics South Africa. (2007). Mid-year population estimates 2007. Pretoria: Statistics South Africa.

Stellman, J.M. (Ed.). (1998). Encyclopaedia of Occupational Health and Safety. (4th edn.). Geneva: International Labour Office.

Strümpfer, D.J.W. (1995). The origins of health and strength: From 'salutogenesis' to 'fortigenesis'. South African Journal of Psychology, 25, 81-89.

Takala, J. (1998, October). Global estimates of fatal occupational accidents. Paper presented at the 16th International Conference of Labour Statisticians, Geneva, Switzerland.

Taris, W.T., Kompier, M.A.J., Geurts, S.A.E., Schreurs, P.J.G., \& Schaufeli, W.B. (2003). Stress management interventions in the Dutch domiciliary care sector: Findings from 81 organizations. International Journal of Stress Management, 10, 297-325.

Temkin, S. (2004, 05 August). Corporate whistle-blowers pay high price of courage. Business Day, n.p.

The South African Institute of International Affairs (2004). AIDS ravages labour force. Retrieved May 21, 2008 from http:// www.saiia.org.za/modules.php?op=modload\&name=New s\&file $=$ article\&sid $=39$

Vaida, G. (2005, n.d.). Sick leave costs SA millions. Sunday Times, p. 1.

Van der Merwe, A. $(2005$, n.d.). Practical stress management. HR Future, p. 17-18.

Whatmore, L., Cartwright, S., \& Cooper, C. (1999). United Kingdom: Evaluation of a stress management programme in the public sector. In M. Kompier \& C.L. Cooper (Eds.), Preventing stress, improving productivity: European case studies in the workplace (pp. 149-171). London: Routledge.

Workmen's Compensation Fund. (1999). Annual report. Johannesburg: WCF.

World Health Organization (2002). Constitution of the World Health Organisation. Retrieved 26 June 26, 2004, from http:// whqlibdoc.who.int/hist/official_records/constitution.pdf)

Wynne, R., \& Rafferty, R. (1999). Ireland: Stress prevention in an airport management company. In M. Kompier \& C.L. Cooper (Eds.), Preventing stress, improving productivity: European case studies in the workplace (pp. 242-261). London: Routledge. 